\title{
Aeromonas fluvialis sp. nov., isolated from a Spanish river
}

Correspondence
Maria J. Figueras
mariajose.figueras@urv.cat

\author{
Anabel Alperi, ${ }^{1}$ Antonio J. Martínez-Murcia, ${ }^{2}$ Arturo Monera, ${ }^{2}$ \\ Maria J. Saavedra ${ }^{2,3}$ and Maria J. Figueras ${ }^{1}$ \\ ${ }^{1}$ Unit of Microbiology, Rovira i Virgili University, IISPV, Sant Llorenç 21, 43201, Reus, Spain \\ ${ }^{2}$ Molecular Diagnostics Center (MDC), Biomolecular Technologies S.L., and Miguel Hernández \\ University, Orihuela E-03300, Alicante. Spain \\ ${ }^{3}$ Department of Veterinary Sciences, CECAV-University of Trás-os-Montes e Alto Douro, Vila Real, \\ Portugal
}

\begin{abstract}
A Gram-stain-negative, facultatively anaerobic bacterial strain, designated $717^{\top}$, was isolated from a water sample collected from the Muga river, Girona, north-east Spain. Preliminary analysis of the 16S rRNA gene sequence showed that this strain belonged to the genus Aeromonas, the nearest species being Aeromonas veronii ( $99.5 \%$ similarity, with seven different nucleotides). A polyphasic study based on a multilocus phylogenetic analysis of five housekeeping genes ( $g y r B$, rpo $D$, recA, dnaJ and gyrA; $3684 \mathrm{bp}$ ) showed isolate $717^{\top}$ to be an independent phylogenetic line, with Aeromonas sobria, Aeromonas veronii and Aeromonas allosaccharophila as the closest neighbour species. DNA-DNA reassociation experiments and phenotypic analysis identified that strain $717^{\top}$ represents a novel species, for which the name Aeromonas fluvialis sp. nov. is proposed, with type strain $717^{\top}$ (=CECT $7401^{\top}=$ LMG $\left.24681^{\top}\right)$.
\end{abstract}

The genus Aeromonas belongs to the class Gammaproteobacteria and to the family Aeromonadaceae, and includes facultatively anaerobic, Gram-negative, nonspore-forming, motile bacilli or coccobacilli that are oxidase- and catalase-positive, able to reduce nitrate to nitrite and are generally resistant to the vibriostatic agent O/129 (Abbott et al., 2003; Martin-Carnahan \& Joseph, 2005). Species of the genus Aeromonas are primarily inhabitants of aquatic environments often associated with fish and human diseases (Martin-Carnahan \& Joseph, 2005; Figueras, 2005). The genus includes 19 species: Aeromonas hydrophila, A. bestiarum, A. salmonicida, A. caviae, A. media, A. eucrenophila, A. sobria, A. veronii, A. jandaei, A. schubertii, A. trota, A. allosaccharophila, A. encheleia, A. popoffii, A. simiae, A. molluscorum, A.

Abbreviations: $A D H$, arginine dihydrolase; LDC, lysine decarboxylase; MLPA, multi locus phylogenetic analysis; ODC, ornithine decarboxylase; VP, Voges-Proskauer test.

The GenBank/EMBL/DDBJ accession numbers for the 16S rRNA, rpo $D$, recA, gyr $B$, dnaJ and gyrA gene sequences of strain $717^{\top}$ are FJ230078, FJ603453, FJ603457, FJ603455, FJ603454 and FJ603456 respectively.

Electron micrographs of strain $717^{\top}$, data showing DNA-DNA relatedness and differences in 16S rRNA gene sequence between strain $717^{\top}$ and type strains of closely related species, and trees derived from $16 \mathrm{~S}$ rRNA gene sequences and MLPA showing the relationship of strain $717^{\top}$ to all other described species of the genus Aeromonas are available as supplementary material with the online version of this paper. bivalvium, the recently described $A$. aquariorum and 'A. tecta' and one unnamed DNA homology group, Aeromonas Group 501 (Harf-Monteil et al., 2004; Miñana-Galbis et al., 2004; Martin-Carnahan \& Joseph, 2005; Miñana-Galbis et al., 2007; Martínez-Murcia et al., 2008; Demarta et al., 2008). There is considerable evidence that the species Aeromonas sharmana (Saha \& Chakrabarti, 2006) may not belong to the genus Aeromonas (MartínezMurcia et al., 2007), while Aeromonas culicicola (Pidiyar et al., 2002) and A. hydrophila subsp. dhakensis (Huys et al., 2002) are potentially considered synonyms of $A$. veronii (Huys et al., 2005) and A. aquariorum (Martínez-Murcia et al., 2009), respectively.

The taxonomy of this genus is complex due to the high inter-species similarity of the 16S rRNA gene sequence, which ranges from 96.7 to $100 \%$ (Martínez-Murcia et al., 2007), the overlap of biochemical profiles and a poor correlation between genotypic and phenotypic identification (Soler et al., 2003; Figueras, 2005; Ormen et al., 2005). Furthermore, the existence of microheterogeneities in the $16 \mathrm{~S}$ rRNA gene sequence could generate misidentifications (Alperi et al., 2008; Morandi et al., 2005). This has recently been shown to occur between A. media and A. hydrophila, A. caviae and A. trota, and A. veronii and A. jandaei (Alperi et al., 2008). Analysis based on the sequences of one or two housekeeping genes has proven to be a useful tool for inferring the taxonomy of the genus Aeromonas (Yañez et al., 2003; Soler et al., 2004; Küpfer et al., 2006; Nhung 
et al., 2007; Sepe et al., 2008). A comprehensive multi locus phylogenetic analysis (MLPA) based on seven housekeeping genes (gyrB, gyrA, rpoD, dnaJ, dnaX, recA and atpD), and including several strains of the 19 described species, demonstrated a robust phylogenetic frame that can be used for taxonomy, revealing a clear differentiation among closely related species of the genus Aeromonas whose positions had previously been questioned (unpublished results).

The present investigation was initiated to determine the taxonomic position of strain $717^{\mathrm{T}}$, a previously undescribed member of the genus Aeromonas that presented a new 16S rRNA gene RFLP pattern when using an RFLP protocol designed to differentiate all species of the genus Aeromonas described prior to 2000 (Figueras et al., 2000). Furthermore, strain $717^{\mathrm{T}}$ appeared as an independent phylogenetic line after analysis of the $r p o D$ gene. In the present study, a polyphasic approach based on an MLPA of five genes (gyrB, gyrA, rpoD, dnaJ and recA), DNA-DNA reassociation experiments and phenotypic analysis was performed to establish the taxonomic allocation of strain $717^{\mathrm{T}}$. Results showed that it represents a novel species of the genus Aeromonas, for which the name Aeromonas fluvialis sp. nov. is proposed.

Strain $717^{\mathrm{T}}$ was isolated from a water sample of the Muga river, Girona, north-east Spain, using the membrane filtration technique and ampicillin dextrin agar, as described previously (Borrell et al., 1998). The strain was genetically confirmed as a member of the genus Aeromonas using the genus probe described by Chacón et al. (2002) and showed a new pattern with the 16S rRNA gene RFLP identification method (Figueras et al., 2000).

The following phenotypic tests used for characterization of strain $717^{\mathrm{T}}$ were selected from Abbott et al. (2003): catalase and oxidase activity, nitrate reduction, hydrogen sulphide production from cysteine, indole production, susceptibility to vibriostatic agent $\mathrm{O} / 129(150 \mu \mathrm{g})$, growth in nutrient broth at 0 and at $6 \% \mathrm{NaCl}$, production of brown diffusible pigment (on TSA) and gas from D-glucose, VogesProskauer (VP) test, $\beta$-galactosidase activity, growth on MacConkey agar, hydrolysis of elastin, gelatin, DNA and urea, and presence of arginine dihydrolase $(\mathrm{ADH})$, lysine decarboxylase (LDC) and ornithine decarboxylase (ODC) by the Moeller's method. Acid production from carbohydrates was determined in nutrient broth at a final concentration of $1 \%(\mathrm{w} / \mathrm{v})$, except for salicin that was at $0.5 \%(\mathrm{w} / \mathrm{v})$, supplemented with phenol red and one of the following substrates: sucrose, L-arabinose, cellobiose, lactose, raffinose, L-rhamnose, myo-inositol, D-mannitol, D-sorbitol, $\mathrm{N}$-acetylglucosamine and salicin (Borrell et al., 1998). These tests were performed at least twice and some of them (production of indole and hydrogen sulphide, VP test, $\beta$-galactosidase activity, presence of $\mathrm{ADH}, \mathrm{LDC}$ and ODC, hydrolysis of gelatin and urea and acid production from D-mannitol, D-sorbitol, L-rhamnose, myo-inositol, sucrose and L-arabinose) were performed in parallel using conventional methods and commercial identification kits (API20NE and API20E, bioMérieux). Finally, 49 carbohydrates for substrate fermentation/oxidation were tested by using API50CH (bioMérieux) following the manufacturer's instructions. Appropriate positive and negative controls were included. All tests were evaluated for 7 days and performed at $30{ }^{\circ} \mathrm{C}$ with the exception of those on $A$. salmonicida, which were tested at room temperature $\left( \pm 25^{\circ} \mathrm{C}\right)$. Type strains belonging to all species of the genus Aeromonas were evaluated under identical conditions to those for strain $717^{\mathrm{T}}$ for all tests included in Table 1.

Isolate $717^{\mathrm{T}}$ was found to be biochemically different from the other species of the genus Aeromonas because of its ability to produce acid from lactose and sucrose but not from L-arabinose or D-mannitol, together with the negative production of $\mathrm{ADH}, \mathrm{LDC}$ (Table 1) and ODC. Acid production from lactose was negative with API50CH but positive on MacConkey agar and in nutrient broth.

Cell size, morphology and the presence of flagella were determined by electron microscopy (Supplementary Fig. S1a, b, available in IJSEM Online) following procedures described previously (Collado et al., 2009).

The susceptibility of strain $717^{\mathrm{T}}$ to 27 antibiotics was tested as described previously (Martínez-Murcia et al., 2008), and the strain was classified as susceptible, intermediate, or resistant according to CLSI standards (CLSI, 2005). The following antibiotic-containing discs were obtained from Oxoid: piperacillin (PRL100), piperacillin plus tazobactam (TZP110), amoxycillin (AML10), amoxycillin plus clavulanic acid (AMC30), ticarcillin (TIC75), ticarcillin plus clavulanic acid (TIM85), cephalothin (KF30), cefoxitin (FOX), cefotaxime (CTX30), cefoperazone (CFP30), ceftazidime (CAZ30), ceftriaxone (CRO30), cefepime (FEP30), aztreonam (ATM30), imipenem (IMP10), gentamicin (CN10), kanamycin (K30), tobramycin (TOB10), amikacin (AK30), streptomycin (S), tetracycline (TE30), ciprofloxacin (CIP5), nalidixic acid (NA), fosfomycin (FOS), erythromycin (E15), trimethoprim/sulfamethoxazole (SxT25) and chloramphenicol (C30).

For phylogenetic study of the $16 \mathrm{~S}$ rRNA and rpoD genes, strain $717^{\mathrm{T}}$ was cultured on blood agar at $30{ }^{\circ} \mathrm{C}$. DNA was extracted from a single colony by using InstaGene Matrix (Bio-Rad) following the manufacturer's instructions. Primers and conditions for amplification and sequencing of the 16S rRNA (1503 bp) and rpoD (820 bp) genes have been described previously (Martínez-Murcia et al., 1992; Soler et al., 2004). PCR products were purified using the GFX PCR DNA and Gel Band Purification kit (Amersham Bioscience) and prepared for sequencing by using the BigDye Terminator v.1.1 cycle sequencing kit (Applied Biosystems). Amplified genes were sequenced with an ABI PRISM 310 genetic analyser (Applied Biosystems). Using the ClUSTAL W program, version 1.83 (Thompson et al., 1994), the sequences obtained were independently aligned with sequences of the type and reference strains of all 
Table 1. Key tests for phenotypic differentiation of strain $717^{\top}$ from other species of the genus Aeromonas.

Taxa: 1, Aeromonas hydrophila; 2, A. bestiarum; 3, A. salmonicida; 4, A. caviae; 5, A. media; 6, A. eucrenophila; 7, A. sobria; 8, A. veronii biovar sobria; 9, A. jandaei; 10, A. veronii biovar veronii; 11, A. schubertii; 12, A. trota; 13, A. encheleia; 14, A. allosaccharophila; 15, A. popoffii [data for taxa $1-15$ from Abbott et al. (2003), tests performed at $35{ }^{\circ} \mathrm{C}$, with two exceptions ${ }^{\star}$ tested at $25{ }^{\circ} \mathrm{C}$ ]; 16 , A. simiae [data from Harf-Monteil et al. (2004)]; 17, A. molluscorum [data from Miñana-Galbis et al. (2004), tests performed at $25^{\circ} \mathrm{C}$ ]; 18 , A. bivalvium [data from Miñana-Galbis et al. (2007), tests

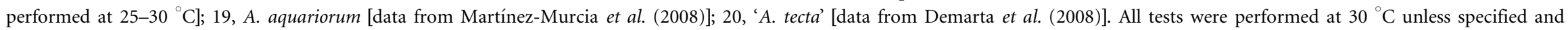

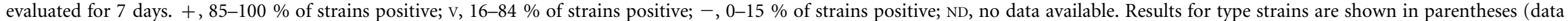
from this study).

\begin{tabular}{|c|c|c|c|c|c|c|c|c|c|c|c|c|c|c|c|c|c|c|c|c|c|}
\hline Chara & $717^{\mathrm{T}}$ & 1 & 2 & 3 & 4 & 5 & 6 & $7^{*}$ & 8 & 9 & 10 & 11 & 12 & 13 & 14 & $15^{\star}$ & 16 & 17 & 18 & 19 & 20 \\
\hline \multicolumn{22}{|l|}{ Presence of: } \\
\hline $\mathrm{ADH}$ & - & $+(+)$ & $+(+)$ & $\mathrm{v}(+)$ & $+(+)$ & $\mathrm{v}(+)$ & $\mathrm{v}(+)$ & $-(+)$ & $+(+)$ & $+(+)$ & $-(-)$ & $+(+)$ & $+(+)$ & $\mathrm{v}(+)$ & $\mathrm{v}(+)$ & $+(+)$ & $+(+)$ & $+(+)$ & $-(+)$ & $+(+)$ & $+(+)$ \\
\hline LDC & - & $+(+)$ & $\mathrm{v}(-)$ & $\mathrm{v}(+)$ & $-(-)$ & $-(-)$ & $-(-)$ & $+(+)$ & $+(+)$ & $+(+)$ & $+(+)$ & $\mathrm{v}(-)$ & $+(+)$ & $-(-)$ & $+(+)$ & $-(-)$ & $+(+)$ & $-(-)$ & $+(+)$ & $+(+)$ & $\mathrm{v}(+)$ \\
\hline $\begin{array}{l}\text { Hydrolysis of: } \\
\text { Gelatin }\end{array}$ & - & $+(+)$ & $\mathrm{v}(+)$ & $+(+)$ & $+(+)$ & $\mathrm{v}(-)$ & $+(+)$ & $-(-)$ & $+(+)$ & $+(+)$ & $+(+)$ & $+(+)$ & $+(+)$ & $-(-)$ & $+(+)$ & $+(+)$ & & $\mathrm{ND}(-)$ & $+(+)$ & $+(+)$ & $\mathrm{ND}(-)$ \\
\hline \multicolumn{22}{|l|}{ Acid from: } \\
\hline Sucrose & + & $+(+)$ & $+(+)$ & $+(+)$ & $+(+)$ & $+(+)$ & $\mathrm{v}(+)$ & $+(+)$ & $+(+)$ & $-(+)$ & $+(+)$ & $-(-)$ & v & $\mathrm{v}(+)$ & $+(+)$ & $-(+)$ & $+(+)$ & $+(+)$ & $+(+)$ & $+(+)$ & $-(-)$ \\
\hline Lactose & + & $\mathrm{V}(-)$ & $-(-)$ & $+(-)$ & $\mathrm{v}(-)$ & $\mathrm{v}(+)$ & $-(+)$ & $-(-)$ & $-(-)$ & $-(-)$ & $\mathrm{v}(-)$ & $-(-)$ & $-(-)$ & $-(-)$ & $-(-)$ & $-(-)$ & $-(-)$ & $-(-)$ & $-(-)$ & $-(-)$ & $-(-)$ \\
\hline D-Mannitol & - & $+(+)$ & $+(+)$ & $+(+)$ & $+(+)$ & $+(+)$ & $+(+)$ & $+(+)$ & $+(+)$ & $+(+)$ & $+(+)$ & $-(-)$ & $\mathrm{v}(+)$ & $+(+)$ & $+(+)$ & $+(+)$ & $-(-)$ & $+(+)$ & $+(+)$ & $+(+)$ & $\mathrm{ND}(+)$ \\
\hline L-Arabinose & - & $\mathrm{v}(+)$ & $+(+)$ & $+(+)$ & $+(+)$ & $+(+)$ & $\mathrm{v}(+)$ & $-(-)$ & $-(+)$ & $-(-)$ & $-(-)$ & $-(-)$ & $-(-)$ & $-(-)$ & $\mathrm{v}(+)$ & $\mathrm{v}(+)$ & $-(-)$ & $+(+)$ & $+(+)$ & $-(-)$ & $-(-)$ \\
\hline Salicin & + & $\mathrm{v}(-)$ & $\mathrm{v}(+)$ & $\mathrm{v}(-)$ & $\mathrm{v}(+)$ & $\mathrm{v}(+)$ & $\mathrm{v}(+)$ & $-(-)$ & $-(-)$ & $-(-)$ & $+(+)$ & $-(-)$ & $-(-)$ & $-(+)$ & $-(-)$ & $-(-)$ & $-(-)$ & $\mathrm{ND}(+)$ & $+(+)$ & $+(+)$ & $\mathrm{v}(-)$ \\
\hline
\end{tabular}


members of the genus Aeromonas available in GenBank. Genetic distances and clustering were determined using Kimura's two-parameter model (Kimura, 1980) and evolutionary trees were reconstructed by the neighbourjoining (16S rRNA and rpoD genes) and maximumparsimony (16S rRNA gene) methods (Saitou \& Nei, 1987) using the MEGA4 program (Tamura et al., 2007). Stability of the relationships was assessed by the bootstrap method (1000 replicates).

The MLPA was performed on the basis of the $\operatorname{gyr} B$ (923 bp), rpoD (652 bp), recA (600 bp), dnaJ (800 bp) and gyrA (709 bp) genes at the Molecular Diagnostic Center (MDC), Orihuela, Spain (unpublished results).

Sequence analysis of the 16S rRNA gene of strain $717^{\mathrm{T}}$ showed the existence of polymorphism (Supplementary Table S1) at seven positions $(0.46 \%)$, all of them within the V3 region. This may hamper correct distinction from the nearest species, A. veronii (Alperi et al., 2008). The $16 \mathrm{~S}$ rRNA gene phylogenetic trees (Fig. 1 and Supplementary Fig. S2) showed strain $717^{\mathrm{T}}$ as an independent phylogenetic line within the genus Aeromonas. The 16S rRNA gene sequence similarity between strain $717^{\mathrm{T}}$ and other species of the genus Aeromonas ranged from $97.6 \%$ to $99.5 \%$, corresponding to $36-7 \mathrm{bp}$ differences, values within the range (96.7-100\%) described for this genus (Saavedra et al., 2006; Martínez-Murcia et al., 2007). The most similar species on the basis of $16 \mathrm{~S}$ rRNA gene sequences were determined to be A. veronii (99.5\%), with 7 bp differences, A. allosaccharophila (99.4\%), with $9 \mathrm{bp}$ differences, followed by A. jandaei (99.1\%), with 13 bp differences. This high similarity is very common within the genus Aeromonas; in fact only one species (A. simiae) of the 19 presently accepted in the genus shows $16 \mathrm{~S}$ rRNA gene sequence similarities below $97 \%$.
The rpoD phylogenetic tree showed strain $717^{\mathrm{T}}$ as an independent phylogenetic line, with $A$. veronii and $A$. allosaccharophila being the phylogenetically closest neighbours $(94.6 \%$ and $94.3 \%$ similarity corresponding to $43 \mathrm{bp}$ and $47 \mathrm{bp}$ differences, respectively) (data not shown). These values were below the intra-species similarities value of $97 \%$ obtained from $r p o D$ phylogeny in the genus Aeromonas (Soler et al., 2004; Alperi et al., 2008). Alignment of the rpoD sequences of strain $717^{\mathrm{T}}$ revealed deletion of a single triplet at the same position as that described for A. trota CECT $4255^{\mathrm{T}}$ (GenBank accession no. AY169344) (Soler et al., 2004).

The MLPA tree showed strain $717^{\mathrm{T}}$ within the cluster of $A$. veronii, $A$. allosaccharophila and $A$. sobria, representing an independent branch (Supplementary Fig. S3). In contrast to that observed with the other genes (16S rRNA and $r p o D)$, the MLPA tree revealed strain $717^{\mathrm{T}}$ to be more distant from $A$. veronii and A. allosaccharophila, with $A$. sobria being the phylogenetically closest neighbour.

DNA-DNA hybridization studies were performed between strain $717^{\mathrm{T}}$ and the type strains of the phylogenetically closest species, A. sobria, A. allosaccharophila, A. veronii and $A$. jandaei, as well as with the unrelated species $A$. molluscorum. DNA was extracted using the method described by Marmur (1961) and DNA-DNA hybridization was conducted using the methods described by Ziemke et al. (1998) and Urdiain et al. (2008). Renaturalization was performed under optimal conditions at $70{ }^{\circ} \mathrm{C}$, single- and double-stranded DNA molecules were separated by the use of hydroxyapatite and colour development was measured at $405 \mathrm{~nm}$ using a Bio Whittaker Kinetic-QCL microplate reader. Values of DNA-DNA reassociation were determined at least three

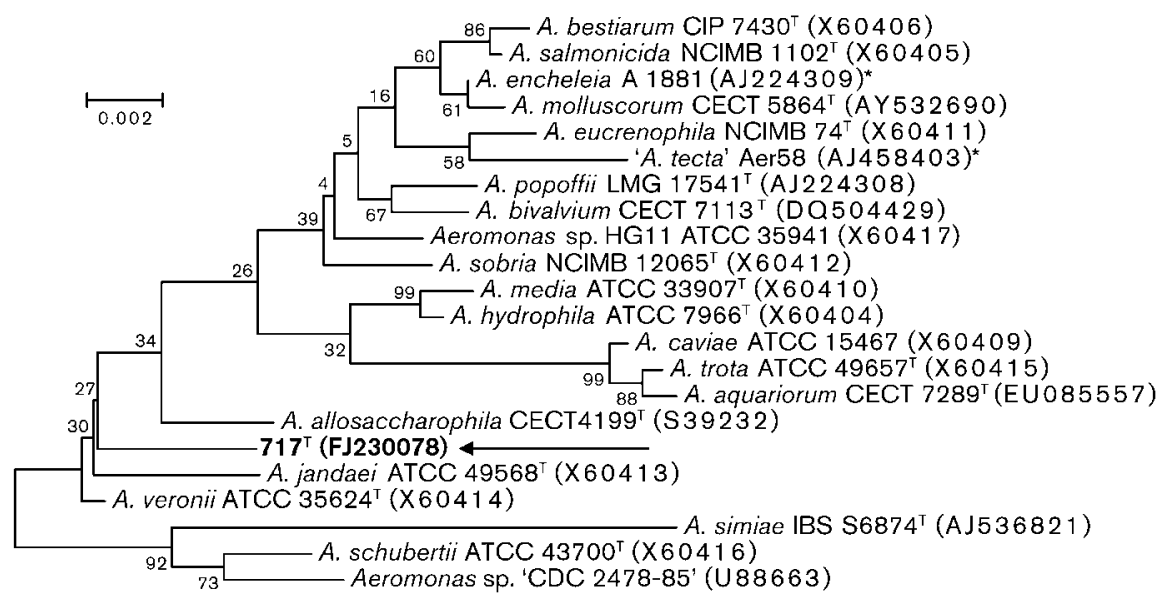

Fig. 1. Unrooted phylogenetic tree derived from 16S rRNA gene sequences showing relationships of strain $717^{\top}$ to all other described species of the genus Aeromonas. The tree was reconstructed using the neighbour-joining method. Numbers at nodes indicate bootstrap values (percentage of 1000 replicates). Bar, 0.002 substitutions per nucleotide position. ${ }^{*}$ Sequence identical to respective type strains. 
times for both direct and reciprocal reactions (e.g. $\mathrm{A} \times \mathrm{B}$ and $\mathrm{B} \times \mathrm{A}$ ) for any given strain pair.

Mean DNA-DNA hybridization levels between strain $717^{\mathrm{T}}$ and the type strains A. sobria CECT $4245^{\mathrm{T}}$, A. allosaccharophila CECT $4199^{\mathrm{T}}$, A. veronii CECT $4257^{\mathrm{T}}$ and $A$. jandaei CECT $4228^{\mathrm{T}}$ were $54 \%, 61 \%, 66 \%$ and $40 \%$, respectively (Supplementary Table S2). All were below the $70 \%$ limit for species delineation (Wayne et al., 1987; Stackebrandt \& Goebel, 1994), but some were above $60 \%$ in concordance with other species of the genus Aeromonas (Huys et al., 1997; Nhung et al., 2007). Despite DNA-DNA reassociation being considered to give information on the DNA similarity between entire bacterial genomes, it has been criticized because of the high number of experimental errors, lack of reproducibility and failure to generate collective databases (Rosselló-Mora, 2006). Moreover, DNA-DNA reassociation values do not provide any information concerning phylogenetic relationships (Harayama \& Kasai, 2006), in contrast to the phylogenetic reconstruction with the MLPA performed previously for members of the genus Aeromonas (unpublished results) and applied in the present study. The polyphasic approach using 16S rRNA gene sequences, MLPA, DNA-DNA reassociation results and phenotypic characterization all clearly differentiated strain $717^{\mathrm{T}}$ from the remaining species of the genus Aeromonas.

\section{Description of Aeromonas fluvialis sp. nov.}

Aeromonas fluvialis (flu.vi.a'lis. L. fem. adj. fluvialis belonging to a river).

Cells are straight, Gram-stain-negative, non-spore-forming rods, non-encapsulated, mobile by single polar flagella, $0.6-0.7 \mu \mathrm{m}$ wide and 3-3.5 $\mu \mathrm{m}$ long, oxidase- and catalasepositive, reduce nitrate to nitrite and are resistant to vibriostatic agent $\mathrm{O} / 129$. Colonies on TSA are $4-5 \mathrm{~mm}$ in diameter, opaque, circular and beige in colour after $48 \mathrm{~h}$ at $30{ }^{\circ} \mathrm{C}$. No brown diffusible pigment is produced on TSA at room temperature or $30{ }^{\circ} \mathrm{C}$. Optimal growth occurs at $30{ }^{\circ} \mathrm{C}$ after $24 \mathrm{~h}$ in TSB. Grows at $37{ }^{\circ} \mathrm{C}$ but not at $4{ }^{\circ} \mathrm{C}$ or $40{ }^{\circ} \mathrm{C}$ on TSA. No haemolysis observed on sheep blood agar at $30{ }^{\circ} \mathrm{C}$. Grows on MacConkey agar and on TSB without $\mathrm{NaCl}$ but not with $6 \% \mathrm{NaCl}$. Optimal growth at $\mathrm{pH} 9$ after $24 \mathrm{~h}$ on TSB but no growth at $\mathrm{pH}$ 4.5. Produces indole from tryptophan and gas from glucose, positive for $\beta$-galactosidase activity and able to use citrate. Negative for production of hydrogen sulphide from cysteine, VP test and hydrolysis of aesculin, gelatin and elastin. No DNase, urease or L-tryptophan deaminase activity. Does not produce $\mathrm{ADH}, \mathrm{LDC}$ or ODC. Able to use D-mannose, Dglucose, $\mathrm{N}$-acetylglucosamine, maltose, potassium gluconate and malic acid as sole carbon and energy sources, but not L-arabinose, D-mannitol, capric acid, adipic acid, phenylacetic acid or trisodium citrate. Acid is produced from glycerol, D-ribose, D-galactose, D-glucose, D-fructose, D-mannose, lactose, $\mathrm{N}$-acetylglucosamine, salicin, cellobiose, maltose, sucrose, trehalose, starch, glycogen, gentio- biose and potassium gluconate, but not from erythritol, Lor D-arabinose, L- or D-xylose, D-adonitol, methyl $\beta$-Dxylopyranoside, L-sorbose, L-rhamnose, dulcitol, inositol, D-mannitol, D-sorbitol, methyl $\alpha$-D-mannopyranoside, methyl $\alpha$-D-glucopyranoside, amygdalin, arbutin, aesculin, melibiose, inulin, melezitose, raffinose, xylitol, turanose, Dlyxose, D-tagatose, L- or D-fucose, L- or D-arabitol, potassium 2-ketogluconate or potassium 5-ketogluconate. Resistant to amoxycillin, amoxycillin plus clavulanic acid and ticarcillin, intermediately resistant to ticarcillin plus clavulanic acid and susceptible to the rest of the antimicrobials tested. The API20E and API20NE profiles obtained for strain $717^{\mathrm{T}}$ were 1240024 and 7062744 respectively.

The type strain is $717^{\mathrm{T}}\left(=\right.$ CECT $\left.7401^{\mathrm{T}}=\mathrm{LMG} 24681^{\mathrm{T}}\right)$, isolated from water of the Muga river, Girona, north-east Spain.

\section{Acknowledgements}

We are grateful to $\mathrm{M}^{\mathrm{a}}$ Jesús Pujalte and to Javier Pascual for their help with the DNA-DNA hybridization, to $\mathrm{M}^{\mathrm{a}}$ Isabel Inza for her help with the phenotypic characterization and to Catalina Nuñez for her excellent technical assistance. We are also grateful to the Pharmacology Unit of the Rovira i Virgili University for use of the Bio Whittaker Kinetic-QCL microplate reader.

\section{References}

Abbott, S. L., Cheung, W. K. \& Janda, J. M. (2003). The genus Aeromonas: biochemical characteristics, atypical reactions, and phenotypic identification schemes. J Clin Microbiol 41, 2348-2357.

Alperi, A., Figueras, M. J., Inza, I. \& Martínez-Murcia, A. J. (2008). Analysis of 16S rRNA gene mutations in a subset of Aeromonas strains and their impact in species delineation. Int Microbiol 11, 185-194.

Borrell, N., Figueras, M. J. \& Guarro, J. (1998). Phenotypic identification of Aeromonas genomospecies from clinical and environmental sources. Can J Microbiol 44, 103-108.

Chacón, M. R., Castro-Escarpulli, G., Soler, L., Guarro, J. \& Figueras, M. J. (2002). A DNA probe specific for Aeromonas colonies. Diagn Microbiol Infect Dis 44, 221-225.

CLSI (2005). Methods for antimicrobial dilution and disk susceptibility testing of infrequently isolated or fastidious bacteria; approved guideline M45-A. Wayne, PA: Clinical and Laboratory Standards Institute.

Collado, L., Cleenwerck, I., Van Trappen, S., De Vos, P. \& Figueras, M. J. (2009). Arcobacter mytili sp. nov., an indoxyl acetate hydrolysisnegative bacterium isolated from mussels. Int J Syst Evol Microbiol 59, 1391-1396.

Demarta, A., Küpfer, M., Riegel, P., Harf-Monteil, C., Tonolla, M., Peduzzi, R., Monera, A., Saavedra, M. J. \& Martínez-Murcia, A. J. (2008). Aeromonas tecta sp. nov., isolated from clinical and environmental sources. Syst Appl Microbiol 31, 278-286.

Figueras, M. J. (2005). Clinical relevance of Aeromonas. Rev Med Microbiol 16, 145-153.

Figueras, M. J., Soler, L., Chacón, M. R., Guarro, J. \& MartínezMurcia, A. J. (2000). Extended method for discrimination of Aeromonas spp. by $16 \mathrm{~S}$ rDNA RFLP analysis. Int $J$ Syst Evol Microbiol 50, 2069-2073.

Harayama, S. \& Kasai, H. (2006). Bacterial phylogeny reconstruction from molecular sequences. In Molecular Identification, Systematics, 
and Population Structure of Prokaryotes, pp. 105-140. Edited by E. Stackebrandt. Berlin, Heidelberg: Springer-Verlag.

Harf-Monteil, C., Fleche, A. L., Riegel, P., Prevost, G., Bermond, D., Grimont, P. A. \& Monteil, H. (2004). Aeromonas simiae sp. nov., isolated from monkey faeces. Int J Syst Evol Microbiol 54, 481-485.

Huys, G., Kämpfer, P., Altwegg, M., Kersters, I., Lamb, A., Coopman, R., Lüthy-Hottenstein, J., Vancanneyt, M., Janssen, P. \& Kersters, K. (1997). Aeromonas popoffii sp. nov., a mesophilic bacterium isolated from drinking water production plants and reservoirs. Int J Syst Bacteriol 47, 1165-1171.

Huys, G., Kämpfer, P., Albert, M. J., Kuhn, I., Denys, R. \& Swings, J. (2002). Aeromonas hydrophila subsp. dhakensis subsp. nov., isolated from children with diarrhoea in Bangladesh, and extended description of Aeromonas hydrophila subsp. hydrophila (Chester 1901) Stanier 1943 (approved lists 1980). Int J Syst Evol Microbiol 52, 705712.

Huys, G., Cnockaert, M. \& Swings, J. (2005). Aeromonas culicicola Pidiyar et al. 2002 is a later subjective synonym of Aeromonas veronii Hickman-Brenner et al. 1987. Syst Appl Microbiol 28, 604-609.

Kimura, M. (1980). A simple method for estimating evolutionary rates of base substitutions through comparative studies of nucleotide sequences. J Mol Evol 16, 111-120.

Küpfer, M., Kuhnert, P., Korczak, B. M., Peduzzi, R. \& Demarta, A. (2006). Genetic relationships of Aeromonas strains inferred from $16 \mathrm{~S}$ rRNA, gyrB and rpoB gene sequences. Int J Syst Evol Microbiol 56, 2743-2751.

Marmur, J. (1961). A procedure for the isolation of deoxyribonucleic acid from microorganisms. J Mol Biol 3, 208-218.

Martin-Carnahan, A. \& Joseph, S. W. (2005). Order XII. Aeromonadales ord. nov. In Bergey's Manual of Systematic Bacteriology, 2nd edn, vol. 2, part B, p. 556. Edited by D. J. Brenner, N. R. Krieg, J. T. Staley \& G. M. Garrity. New York: Springer.

Martínez-Murcia, A. J., Benlloch, S. \& Collins, M. D. (1992). Phylogenetic interrelationships of members of the genera Aeromonas and Plesiomonas as determined by $16 \mathrm{~S}$ ribosomal DNA sequencing: lack of congruence with results of DNA-DNA hybridizations. Int J Syst Bacteriol 42, 412-421.

Martínez-Murcia, A. J., Figueras, M. J., Saavedra, M. J. \& Stackebrandt, E. (2007). The recently proposed species Aeromonas sharmana sp. nov., isolate GPTSA-6T, is not a member of the genus Aeromonas. Int Microbiol 10, 61-64.

Martínez-Murcia, A. J., Saavedra, M. J., Mota, V. R., Maier, T., Stackebrandt, E. \& Cousin, S. (2008). Aeromonas aquariorum sp. nov., isolated from aquaria of ornamental fish. Int J Syst Evol Microbiol 58, 1169-1175.

Martínez-Murcia, A. J., Monera, A., Alperi, A., Figueras, M. J. \& Saavedra, M. J. (2009). Phylogenetic evidence suggests that strains of Aeromonas hydrophila subsp. dhakensis belong to the species Aeromonas aquariorum sp. nov. Curr Microbiol 58, 76-80.

Miñana-Galbis, D., Farfán, M., Fusté, M. C. \& Lorén, J. G. (2004). Aeromonas molluscorum sp. nov., isolated from bivalve molluscs. Int $J$ Syst Evol Microbiol 54, 2073-2078.

Miñana-Galbis, D., Farfán, M., Fusté, M. C. \& Lorén, J. G. (2007). Aeromonas bivalvium sp. nov., isolated from bivalve molluscs. Int $J$ Syst Evol Microbiol 57, 582-587.

Morandi, A., Zhaxybayeva, O., Gogarten, J. P. \& Graf, J. (2005). Evolutionary and diagnostic implications of intragenomic heterogeneity in the 16S rRNA gene in Aeromonas strains. J Bacteriol 187, 65616564 .

Nhung, P. H., Hata, H., Ohkusu, K., Noda, M., Shah, M. M., Goto, K. \& Ezaki, T. (2007). Use of the novel phylogenetic marker dnaJ and
DNA-DNA hybridization to clarify interrelationships within the genus Aeromonas. Int J Syst Evol Microbiol 57, 1232-1237.

Ormen, O., Granum, P. E., Lassen, J. \& Figueras, M. J. (2005). Lack of agreement between biochemical and genetic identification of Aeromonas spp. APMIS 113, 203-207.

Pidiyar, V., Kaznowski, A., Narayan, N. B., Patole, M. \& Shouche, Y. S. (2002). Aeromonas culicicola sp. nov., from the midgut of Culex quinquefasciatus. Int J Syst Evol Microbiol 52, 1723-1728.

Rosselló-Mora, R. (2006). DNA-DNA reassociation applied to microbial taxonomy and their critical evaluation. In Molecular Identification, Systematics, and Population Structure of Prokaryotes, pp. 23-50. Edited by E. Stackebrandt. Berlin: Springer.

Saavedra, M. J., Figueras, M. J. \& Martínez-Murcia, A. J. (2006). Updated phylogeny of the genus Aeromonas. Int J Syst Evol Microbiol 56, 2481-2487.

Saha, P. \& Chakrabarti, T. (2006). Aeromonas sharmana sp. nov., isolated from a warm spring. Int J Syst Evol Microbiol 56, 1905-1909.

Saitou, N. \& Nei, M. (1987). The neighbor-joining method: a new method for reconstructing phylogenetic trees. Mol Biol Evol 4, 406425.

Sepe, A., Barbieri, P., Peduzzi, R. \& Demarta, A. (2008). Evaluation of recA sequencing for the classification of Aeromonas strains at the genotype level. Lett Appl Microbiol 46, 439-444.

Soler, L., Marco, F., Vila, J., Chacón, M. R., Guarro, J. \& Figueras, M. J. (2003). Evaluation of two miniaturized systems, MicroScan W/A and BBL Crystal E/NF, for identification of clinical isolates of Aeromonas spp. J Clin Microbiol 41, 5732-5734.

Soler, L., Yañez, M. A., Chacón, M. R., Aguilera-Arreola, M. G., Catalán, V., Figueras, M. J. \& Martínez-Murcia, A. J. (2004). Phylogenetic analysis of the genus Aeromonas based on two housekeeping genes. Int J Syst Evol Microbiol 54, 1511-1519.

Stackebrandt, E. \& Goebel, B. M. (1994). Taxonomic note: a place for DNA-DNA reassociation and $16 \mathrm{~S}$ rRNA sequence analysis in the present species definition in bacteriology. Int J Syst Bacteriol 44, 846849.

Tamura, K., Dudley, J., Nei, M. \& Kumar, S. (2007). MEGA4: molecular evolutionary genetics analysis (MEGA) software version 4.0. Mol Biol Evol 24, 1596-1599.

Thompson, J. D., Higgins, D. G. \& Gibson, T. J. (1994). CLUSTAL W: improving the sensitivity of progressive multiple sequence alignment through sequence weighting, position-specific gap penalties and weight matrix choice. Nucleic Acids Res 22, 4673-4680.

Urdiain, M., López-López, A., Gonzalo, C., Busse, H. J., Langer, S., Kämpfer, P. \& Rosselló-Móra, R. (2008). Reclassification of Rhodobium marinum and Rhodobium pfennigii as Afifella marina gen. nov. comb. nov. and Afifella pfennigii comb. nov., a new genus of photoheterotrophic Alphaproteobacteria and emended descriptions of Rhodobium, Rhodobium orientis and Rhodobium gokarnense. Syst Appl Microbiol 31, 339-351.

Wayne, L. G., Brenner, D. J., Colwell, R. R., Grimont, P. A. D., Kandler, O., Krichevsky, M. I., Moore, L. H., Moore, W. E. C., Murray, R. G. E. \& other authors (1987). International Committee on Systematic Bacteriology. Report of the ad hoc committee on reconciliation of approaches to bacterial systematics. Int J Syst Bacteriol 37, 463-464.

Yañez, M. A., Catalán, V., Apraiz, D., Figueras, M. J. \& MartínezMurcia, A. J. (2003). Phylogenetic analysis of members of the genus Aeromonas based on gyrB gene sequences. Int J Syst Evol Microbiol 53, 875-883.

Ziemke, F., Hofle, M. G., Lalucat, J. \& Rosselló-Mora, R. (1998). Reclassification of Shewanella putrefaciens Owen's genomic group II as Shewanella baltica sp. nov. Int J Syst Bacteriol 48, 179-186. 